\title{
Hak Cipta Sebagai Objek Jaminan Fidusia dalam Undang-Undang Republik Indonesia Nomor 28 Tahun 2014 Tentang Hak Cipta
}

\author{
Soni Ramdani \\ Program Studi Magister Ilmu Hukum \\ Pascasarjana Universitas Islam Bandung \\ Email: soniramdhani7@yahoo.com
}

\begin{abstract}
Abstrak - Hak cipta sebagai objek jaminan fidusia masih terdapat beberapa isu hukum dalam pelaksanaannya. Isu hukum tersebut meliputi ruang lingkup masalah nilai, kepemilikan, pengalihan hak dan pengajuan hak cipta sebagai objek jaminan. Isu-isu hukum tersebut timbul karena belum adanya regulasi yang khusus mengenai hak cipta apa saja yang dapat menjadi objek jaminan. Keadaan tersebut menimbulkan risiko yang cukup besar bagi pihak lembaga peminjaman uang untuk dapat menerima hak cipta sebagai suatu objek jaminan. Penelitian ini bertujuan untuk mengetahui dan memahami pembebanan Hak Cipta atas lagu sebagai Objek Jaminan Fidusia berdasarkan UndangUndang Nomor 42 Tahun 1999 tentang Jaminan Fidusia, dan penyerahan hak milik atas benda jaminan fidusia dalam hal hak cipta sebagai objeknya. Metode pendekatan yang digunakan dalam penelitian ini adalah yuridis normatif, dengan spesifikasi penelitian deskriptif analitis. Data yang digunakan adalah data sekunder yang terdiri dari bahan hukum primer, sekunder, dan tersier yang berkaitan dengan pembebanan hak cipta atas lagu sebagai objek jaminan fidusia yang diperoleh dari studi kepustakaan. Hasil dari penelitian ini menunjukkan bahwa hak cipta dalam bentuk ciptaan lagu dapat dibebani jaminan fidusia berdasarkan Undang-Undang Nomor 42 Tahun 1999 tentang Jaminan Fidusia, karena ciptaan lagu merupakan benda bergerak tidak berwujud. Namun ciptaan lagu yang dapat dijadikan objek jaminan adalah ciptaan lagu yang memiliki nilai ekonomis. Nilai ekonomis dari suatu ciptaan itu dapat dilihat dari seberapa banyak royalti yang didapatkan oleh pencipta dari ciptaannya tersebut. Penyerahan Hak milik atas Objek Jaminan Fidusia dalam hal objeknya adalah Hak cipta dapat dilakukan berdasarkan penyerahan Constitutum Possesorium.
\end{abstract}

\section{Kata Kunci: Hak Kekayaan Intelektual, Hak Cipta, Jaminan Fidusia}

\begin{abstract}
Copyright as a fiduciary object still has several legal issues in its implementation. The legal issues include the scope of value, ownership, transfer of rights, and filing of copyright as collateral objects. These legal issues arise because there are no specific regulations regarding any copyright that can be collateral objects. This situation poses a considerable risk for the lending institution to receive copyright as a collateral object. This study aimed at determining and understanding the imposition of copyright on songs as a fiduciary guarantees based on Law Number 42 Year 1999 concerning Fiduciary Guarantees, and the transfer of ownership rights to fiduciary guarantees in terms of copyright as their objects. The method used normative juridical, with descriptive-analytical research specifications. The data used secondary data consisting of primary, secondary, and tertiary legal material relating to the imposition of copyright on songs as fiduciary guarantees obtained from literature studies. The result indicates that copyright in the form of song creation can be burdened with fiduciary guarantees based on Law Number 42 Year 1999 concerning Fiduciary Guarantees because song creation is an intangible movable object. However, song compositions that can be used as collateral
\end{abstract}


objects are song compositions that have economic value. The economic value of a work can be seen from how much royalty is obtained by the creator of the work. Transfer of property rights over fiduciary guarantees, if the object is a copyright, can be made based on the transfer of Constitutum Possesorium.

\section{Keywords: Intellectual Property Rights, Copyrights, Fiduciary Guarantees}

\section{A. PENDAHULUAN}

Karya ilmu pengetahuan atau scientific meliputi ciptaan; buku, program komputer, pamflet, perwajahan atau lay out, karya tulis yang diterbitkan, dan semua hasil karya tulis yang lain; ceramah, pidato, dan ciptaan lain yang sejenis dengan itu; alat peraga yang dibuat untuk kepentingan pendidikan dan ilmu pengetahuan; arsitektur, dan peta. Sedangkan karya seni mencakup; lagu atau musik dengan atau tanpa teks; drama atau drama musikal, tari, kreografi, pewayangan, dan pantomim; seni rupa dalam segala bentuk seperti seni lukis, gambar, seni ukir, seni kaligrafi, seni pahat, seni patung, kloase, dan seni terapan; seni batik, fotografi, dan sinematografi. Adapun karya sastra atau literary work diantaranya adalah; terjemaahan, tafsir, saduran, bunga rampai, database dan karya lain dari hasil pengalih wujudan. Dari uraian mengenai jenis-jenis ciptaan tersebut, karya ilmu pengetahuan dan karya sastra memiliki media tertulis baik yang berupa buku, karya tulis ilmiah, seperti disertasi, tesis, skripsi dan makalah maupun yang berupa artikel untuk jurnal, bulletin, majalah atau koran. ${ }^{1}$

Zaman modern merupakan zaman di mana manusia dituntut untuk mengembangkan diri. Artistik identik dengan seni, karena itulah manusia sering disebut makhluk berkesenian. Manusia dapat dikatakan sebagai makhluk yang memiliki keistimewaan. Adanya suatu keistimewaan ini melahirkan hak dari manusia tersebut untuk mendapat pengakuan, dihargai, dan dihormati. Teori yang sering muncul dalam sejarah pikiran manusia ialah bahwa keistimewaan manusia terletak dalam wujud manusia itu sendiri, sebagaimana didapati melalui

\footnotetext{
${ }^{1}$ Henry Soelistyo, Hak Cipta Tanpa Hak Moral, PT. Raja Grafindo Persada, Jakarta, 2011, Hlm. 185
} 
pikirannya, maka keistimewaan manusia itu bersifat rasional. Hakhak yang didapati orang secara rasional dianggap abadi dan tetap berlaku. Tiap-tiap orang lain, termasuk pemerintah harus mengindahkannya, dengan membuat hukum atas dasar hak-hak alamiah tersebut. $^{2}$

Salah satu aspek hukum yang melindungi hak-hak manusia dalam hak intelektualnya adalah Hukum Hak Kekayaan Intelektual (HKI). Sebagai bentuk penghargaan atas Hak Kekayaaan Intelektual (HKI), perlindungan hukum atas hak-hak tersebut memerlukan perangkat hukum dan mekanisme perlindungan yang memadai. Melalui cara inilah HKI akan mendapat tempat yang layak sebagai salah satu bentuk hak yang memiliki nilai ekonomis. Hukum HKI adalah hukum yang mengatur perlindungan bagi para pencipta dan penemu karya-karya inovatif sehubungan dengan pemanfaatan karya-karya mereka

${ }^{2}$ Maria Alfons, Implementasi Hak Kekayaan Intelektual Dalam Perspektif Negara Hukum, Jurnal legislalasi Indonesia, Vol. 14 No. 03 - September 2017, Hlm. 2 secara luas dalam masyarakat. Karena itu tujuan hukum HKI adalah menyalurkan kreativitas individu untuk kemanfaatan manusia secara luas. $^{3}$

Hak kekayaan intelektual yang selanjutnya disebut dengan (KI) merupakan hak eksklusif yang diberikan Negara kepada individu pelaku KI, tidak lain di maksud sebagai penghargaan atas karya yang dimiliki pemiliknya, sehingga pemilik KI berhak atas pemanfaatan, penjualan, serta kegiatan lain berkenaan dengan kekayaan intelektual yang dimilikinya. Hak Cipta sebagai bagian dari KI sesuai dengan pasal 1 ayat (1) UndangUndang Nomor 28 Tahun 2014 tentang Hak Cipta (UU Nomor 28 Tahun 2014) adalah hak eksklusif pencipta yang timbul secara otomatis berdasarkan prinsip deklaratif setelah suatu ciptaan diwujudkan dalam bentuk nyata tanpa mengurangi pembatasan sesuai dengan ketentuan peraturan perundang-undangan pengertian. Hak Cipta menurut

\footnotetext{
${ }^{3}$ Sulasi Rongiyati, Pelindungan Hukum Hak Kekayaan Intelektual Pada Produk Ekonomi Kreatif, Negara Hukum: Vol. 9, No. 1, Juni 2018, Hlm. 2
} 
Mckeong dan Stewart, Hak Cipta adalah suatu konsep di mana pencipta (artis, musisi, pembuat film) yang memiliki hak untuk memanfatkan hasil karyanya tanpa meperbolehkan pihak lain untuk neniru hasil karyanya tersebut. ${ }^{4}$ Hak cipta dapat dibagi atas dua jenis. Pertama, hak cipta bersifat orisinil (asli) dan kedua, hak cipta bersifat derivatif (turunan). Hak cipta bersifat orisinil member hak atau wewenang kepada pencipta yang sebenarnya, seperti kepada seorang pengarang buku, puisi, lagu, dan jenis hak cipta lainnya, sedangkangkan hak cipta yang bersifat derivative muncul dari pemegang hak cipta yang orisinil seperti, melalui hibah, wasiat, pewarisan dan pembelian. ${ }^{5}$ Hak cipta memiliki nilai ekonomi dan dapat dialihkan baik seluruhnya maupun sebagaian karena pewarisan, hibah, wasiat, perjanjian tertulis atau sebabsebab lain yang dibenarkan oleh peraturan perundang-undangan, oleh

4 Afillyana Purba, Gazalba Saleh dan Andriana Krisnawati, , TrIps-WTO dan HUKUM HKI Indonesia, PT Rineka Cipta, Jakarta, 2015, Hal.32.

5 Muhammad Abdulkadir, Kajian Hukum Ekonomi Hak Kekayaan Intelektual, PT. Citra Aditya Bakti, Bandung, 2001, Hal.4 karena itu hak cipta mempunyai prospek untuk dijadikan sebagai agunan kredit.

Ketentuan KUH Perdata tidak mengatur Jaminan Fidusia, hanya memuat mengenai gadai dan hipotik sebagai konsekuensi adanya pembagian jenis benda bergerak dan tidak bergerak. Gadai mengatur jaminan yang objeknya adalah benda bergerak dan hipotek mengatur jaminan dengan objek benda tidak bergerak. Pranata hukum jaminan tersebut, pada saat itu dirasakan telah memenuhi kebutuhan masyarakat akan hukum jaminan dalam perkreditan. Pada lembaga gadai (pand), benda gadai harus berada dalam kekuasaan pemegang gadai. Hak gadai tersebut hapus apabila benda gadai itu terlepas dari kekuasaan pemegang gadai. Persyaratan gadai ini mengandung kekurangan terutama bagi kalangan usaha kecil dan menengah yang masih membutuhkan benda-benda jaminan tersebut untuk mendukung kegiatan usahanya sehari-hari. Begitu juga kalau meminjam uang ke bank guna keperluan menambah modal, mereka akan terbentur dengan 
adanya syarat pemberian kredit bank dengan jaminan berupa agunan sertifikat tanah.

Oleh karena ada kebutuhan dalam praktek untuk menjaminkan barang bergerak, tetapi tanpa penyerahan barang secara fisik. Untuk maksud tersebut tidak dapat digunakan lembaga gadai (yang mensyaratkan penyerahan benda) dan juga tidak dapat digunakan hipotik (yang hanya diperuntukkan terhadap barang tidak bergerak saja). ${ }^{6}$

Lebih khususnya, mengenai salah satu jenis benda yang tergolong

dalam benda bergerak tidak berwujud yaitu Hak Cipta. Perkembangan peraturan mengenai Hak Cipta ini dari waktu ke waktu mengalami beberapa perubahan. Secara yuridis formal Indonesia memperkenalkan hak cipta pada tahun 1912, yaitu pada saat diundangkannya Auteurswet (Wet van 23 September 1912, staatsblad 1912 Nomor 600). ${ }^{7}$

\footnotetext{
${ }^{6}$ Henry Donald Lbn. Toruan, Problematika Implementasi Pembiayaan Dengan Perjanjian Jaminan Fidusia, Jurnal Penelitian Hukum DE JURE, ISSN 14105632 Vol. 18 No. 2, Juni 2018, Hlm. 1

7 Rachmadi Usman, Hukum atas Hak Kekayaan Intelektual: Perlindungan dan
}

Dalam Undang-Undang Nomor 28 Tahun 2014 tentang Hak Cipta (UUHC) inilah ada sesuatu hal baru yang diatur yakni mengenai Hak Cipta yang dapat dijadikan sebagai Objek Jaminan Fidusia. Dalam Pasal 16 Ayat (1) dan Ayat (3) UUHC diatur Hak Cipta sebagai benda bergerak tidak berwujud dan dapat dijadikan sebagai objek Jaminan Fidusia.

Berdasarkan aturan baru tersebut maka para pencipta dapat menjaminkan ciptaannya. Namun kehadiran peraturan baru tersebut tidak serta merta membuat para pencipta dengan mudah untuk mendaftarkan ciptaannya sebagai objek jaminan, dikarenakan belum adanya peraturan lebih lanjut mengenai hal tersebut. Hak Cipta sebagai Objek jaminan fidusia diatur dalam Pasal 16 Ayat (3) bahwa, "Hak Cipta dapat dijadikan sebagai objek jaminan fidusia". Pengaturan dalam Pasal 16 Ayat (3) ini memang membutuhkan penjabaran lebih lanjut, mengenai pembebanan hak cipta sebagai objek jaminan fidusia

Dimensi Hukumnya di Indonesia, Alumni, Bandung, 2003, hlm.56 
dalam hal hak cipta apa saja yang dapat dijadikan sebagai jaminan. ${ }^{8}$

yang dihadapi di Indonesia adalah belum tersedianya suatu ketentuan tentang penggunaan hak cipta sebagai jaminan dalam lembaga peminjaman uang serta belum tersedianya lembaga penilai yang memiliki kemampuan untuk memberikan penilaian terhadap nilai ekonomi dari hak cipta. Di negara lain seperti di Amerika Serikat, jaminan terhadap barang bergerak tidak berwujud seperti hak cipta sudah diatur. ${ }^{9}$

Pengaturan dalam Pasal 16 Ayat (3) terkait dan bahkan bergantung pada undang-undang yang lain, seperti yang diatur dalam Pasal 16 Ayat (4) bahwa "Ketentuan mengenai hak cipta sebagai objek jaminan fidusia sebagaimana dimaksud pada ayat (3) dilaksanakan sesuai dengan ketentuan peraturan perundangundangan.'Peraturan perundangundangan yang paling dekat adalah Undang-undang Nomor 42 Tahun

\footnotetext{
${ }^{8}$ Lebih jelas dapat dilihat dalam Pasal 16 Undang-undang Nomor 28 tahun 2014 tentang Hak Cipta

${ }^{9}$ http://businesslaw.binus.ac.id/2015/10/08/h ak-cipta-sebagai-objek-jaminan - fidusia/ diakses pada tanggal 25 April 2019
}

1999 tentang Jaminan Fidusia.

Jika mengacu pada Pasal 1 butir 2 Undang Undang tentang Jaminan Fidusia, Hak cipta telah memenuhi syarat yang diatur pada Pasal 1 butir 2 tersebut namun pihak lembaga peminjaman uang di Indonesia belum mempraktikan hak cipta sebagai jaminan jika hanya berdasarkan ketentuan tersebut.Di dalam Undangundang Nomor 42 tahun 1999 tentang Jaminan Fidusia (UUJF) belum dijelaskan secara luas mengenai kemilikan objekjaminan fidusia tersebut.

Pemberi fidusia menyerahkan secara kepercayaan hak miliknya sebagai jaminan hutang kepada penerima fidusia. Penyerahan hak milik atas benda jaminan fidusia tidaklah sempurna sebagaimana pengalihan hak milik dalam perjanjian jual-beli. Dalam perjanjian jaminan fidusia, pengalihan hak masih bergantung kepada suatu syarat, yakni apabila pemberi fidusia melakukan wanprestasi. ${ }^{10}$

Menurut penulis mengenai Hak cipta sebagai objek jaminan fidusia masih

\footnotetext{
10 Tan Kamelo, Hukum Jaminan Fidusia suatu Kebutuhan yang didambakan, Alumni, Bandung, 2006, hlm.190
} 
terdapat beberapa isu hukum dalam pelaksanaannya. Isu hukum tersebut meliputi ruang lingkup masalah nilai, kepemilikan, pengalihan hak dan pengajuan hak cipta sebagai objek jaminan. Isu-isu hukum tersebut timbul karena belum adanya regulasi yang khusus mengenai hak cipta apa saja yang dapat menjadi objek jaminan. Keadaan tersebut menimbulkan risiko yang cukup besar bagi pihak lembaga peminjaman uang untuk dapat menerima hak cipta sebagai suatu objek jaminan.

\section{B. Rumusan Masalah}

1. Bagaimana pembebanan Hak Cipta atas lagu sebagai Objek Jaminan Fidusia berdasarkan Undang-Undang Nomor 42 Tahun 1999 tentang Jaminan Fidusia?

2. Bagaimana penyerahan hak milik atas benda jaminan fidusia dalam hal hak cipta sebagai objeknya?

\section{Pembahasan}

1. Pembebanan Hak Cipta atas lagu sebagai Objek Jaminan Fidusia berdasarkan Undang-

\section{Undang Nomor 42 Tahun 1999 tentang Jaminan Fidusia}

Hak cipta telah memeberikan kewenangan yang besar bagi para pencipta. Sesuai dengan pengertian Hak Kekayaan Intelektual (HKI), hak cipta dapat diartikan sebagai hak milik yang melekat pada karya-karya cipta di bidang kesusasteraan, seni, dan ilmu pengetahuan seperti karya tulis, karya musik, lukisan, patung dan sebagainya. Pada hakikatnya, hak cipta adalah hak yang dimiliki pencipta untuk mengeksploitasi dengan berbagai cara karya cipta yang dihasilkan. ${ }^{11}$

Di dalam Undang-undang Hak cipta 2014 (UUHC), Hak cipta adalah hak eksklusif pencipta yang timbul secara otomatis berdasarkan prinsip deklaratif setelah suatu ciptaan diwujudkan dalam bentuk nyata tanpa mengurangi pembatasan sesuai dengan ketentuan peraturan perundang-undangan. Namun, hal ini masih perlu untuk diperjelas, karena walaupun hak cipta bersifat eksklusif, pemegang hak cipta tidak

11 Bernard Nainggolan, Pemberdayaan Hukum Hak Cipta dan Lembaga Manajemen Kolektif, Alumni, Bandung, 2011, hlm.7475. 
mudah mempertahankannya.

Hak cipta sebagai hak milik membawa konsekuensi bahwa pencipta mendapat perlindungan atau proteksi hukum terhadap pemanfaatan hak cipta secara tidak ah atau tanpa izin pencipta. Pemanfaatan suatu ciptaan oleh pencipta tidak berlangsung abadi atau untuk selamanya. Jika penggunaan ciptaan oleh masyarakat dilakukan secara bebas adalah tidak adil bagi pencipta, sebaliknya pemanfaatan ciptaan tanpa batas waktu oleh pencipta juga membawa ketidakadilan bagi masyarakat.

Berdasarkan UUHC pasal 16 ayat (1), diatur bahwa hak cipta merupakan benda bergerak tidak berwujud. Benda bergerak tidak berwujud ialah benda yang timbul dari hubungan tertentu atau hasil perdata(burgelijke vruchten). Di dalam Pasal 511 angka 3 KUH Perdata tersirat bahwa benda bergerak tidak berwujud sebenarnya adalah hak yang dilekatkan pada suatu benda tertentu yang memiliki wujud, maka

sifat itu dapat juga dilihat dari penggolongan perikatan dan tuntutan mengenai jumlah uang yang dapat ditagih atau mengenai benda bergerak sebagai suatu hak yang digolongkan sebagai benda bergerak. $^{12}$

Pada Hukum Keperdataan, Hak cipta merupakan suatu hak kekayaan immateril yaitu suatu hak kekayaan yang objek haknya adalah benda bergerak tidak berwujud. Di dalam Pasal 499 KUH Perdata diatur bahwa "menurut paham undang-undang yang dinamakan benda ialah tiap-tiap hak yang dapat dikuasai menjadi objek kekayaan(property) atau hak milik." Berdasarkan rumusan tersebut maka Hak kekayaan immateril termasuk ke dalam hakhak yang disebut Pasal 499 KUH Perdata. Oleh sebab itu, hak kekayaan immateril itu sendiri dapat menjadi objek dari sesuatu hak kebendaan. $^{13}$

Hak kebendaan merupakan hak absolut atas sesuatu benda, tetapi ada

12 Junaidi Akhmad dan Muhammad Joni. Pemanfaatan Sertifikat HKI Sebagai Collateral Kredit. Jurnal Volume 6, 2011, hlm. 6

${ }^{13}$ Hariyani, Iswi dan Cita Yustisia Serfiyani, 2015, Peran HKI dalam Pengembangan Waralaba dan Ekonomi Kreatif, Media HKI, Vol. XII, No.6, November Ditjen HKI, Kemenkumham RI, Jakarta. 2015, hlm. 5 
hak absolut yang objeknya bukan benda berwujud (barang). Itulah yang disebut dengan Hak Kekayaan Intelektual (Intellectual property rights).

Meningkatnya kegiatan ekonomi tentunya mempengaruhi tingkat kebutuhan akan dana bagi setiap masyarakat maupun badan hukum. Berdasarkan hal tersebut maka kebanyakan masyrakat ataupun badan hukum memilih untuk meminta bantuan dana melalui perkreditan.

Asas hukum perjanjian yang berhubungan dengan pembebanan hak cipta sebagai jaminan fidusia adalah prinsip kebebasan berkontrak, pacta sunt servanda, dan itikad baik.

Pembebanan fidusia harus didasarkan atas perjanjian yang dibuat pencipta atau pemegang hak cipta dengan pemberi kredit atas dasar kebebasan berkontrak. Perjanjian yang telah dibuat oleh para pihak tersebut bersifat mengikat karena itu harus ditaati. Selanjutnya kedua belah pihak (pencipta atau pemegang hak cipta dengan pemberi kredit) harus mempunyai itikad baik, dalam arti melaksanakan perjanjian sesuai dengan apa yang telah disepakati. ${ }^{14}$

Fidusia merupakan suatu perjanjian tambahan (accesoir) didasarkan atas perjanjian pokoknya yaitu pemberian kredit yang didasarkan pada ketentuan Pasal 1313 KUH Perdata yang mengatur bahwa "suatu persetujuan adalah suatu perbuatan dengan mana satu orang atau lebih mengingatkan dirinya terhadap satu orang atau lebih."

Pembebanan jaminan fidusia diatur mulai dari Pasal 4 sampai dengan Pasal 10 Undang-undang Nomor 42 Tahun 1999 tentang Jaminan Fidusia (UUJF). Jaminan fidusia merupakan perjanjian tambahan dari perjanjian pokok yang menimbulkan kewajiban bagi para pihak untuk memenuhi suatu prestasi. ${ }^{15}$

Hak cipta atas lagu jika diajukan sebagai objek jaminan maka sebelumnya ciptaan lagu tersebut harus terdaftar di Kementrian Hukum

${ }^{14}$ Kartini Muljadi dan Gunawan Widjaja, Seri Hukum Harta Kekayaan: Kebendaan pada Umumnya, Cetakan ke-2, Kencana, Jakarta, 2003, hlm.80-81

${ }^{15}$ Hariyani, Iswi, , Hak Kekayaan Intelektual Sebagai Jaminan Kredit, dalam Media HKI, Vol. VII, No. 03, Juni 2010, Ditjen HKI, Kemenkumham RI, Jakarta. Hlm. 4 
dan HAM Republik Indonesia untuk dimasukkan di dalam Daftar Umum Ciptaan, setelah di daftarkan maka selanjutnya dapat dikatakan milik sah dari si Pencipta. Pendaftaran Hak Cipta diajukan dengan Permohonan secara tertulis dalam bahasa Indonesia oleh pencipta, pemegang hak cipta, pemilik hak terkait, atau Kuasanya kepada Menteri. Permohonan dilakukan secara elektronik maupun non elektronik dengan menyertakan contoh ciptaan, hak terkait, atau penggantinya, melampirkan surat pernyataan kepemilikan ciptaan dan hak terkait, dan membayar biaya. Setelah diajukan permohonan, menteri berhak melakukan pemeriksaan terhadap permohonan tersebut. Pemeriksaan dilakukan untuk mengetahui ciptaan atau hak terkait yang dimohonkan tersebut secara esensial sama atau tidak sama dengan ciptaan yang tercatat dalam daftar umum ciptaan atau objek kekayaan intelektual lainnya. ${ }^{16}$

\footnotetext{
${ }^{16}$ Subagio Gigih Wijaya, Hak Cipta sebagai Jaminan Utang, Universitas Sebelas Maret, Surakarta, 2010, hlm.131
}

Prosedur pendaftaran hak cipta adalah sebagai berikut: ${ }^{17}$

1. Setelah pengajuan permohonan pencatatan hak cipta, Direktorat Jenderal Kekayaan Intelektual akan melakukan pemeriksaan administratif mengenai kelengkapan dokumen.

2. Jika dalam pemeriksaan administratif dokumen belum lengkap, pemohon diberi waktu 3 bulan untuk melengkapinya.

3. Ditjen KI kemudian akan melakukan evaluasi dan jika tidak ada keberatan terhadap permohonan pencatatan hak cipta, Direktorat Jenderal Kekayaan Intelektual akan mengeluarkan Surat Pencatatan Ciptaan dan mencatat dalam daftar umum Ciptaan.

Setelah ciptaannya terdaftar, maka untuk mendapatkan hasil ekonomi dari ciptaannya sebaiknya

\footnotetext{
17 Hendra Tanu Atmadja. Konsep Hak ekonomi dan Hak moral Pencipta menurut Sistem Civil Law dan Common Law. Jakarta:Jurnal Hukum Nomor 23 Volume 10, 2015, hlm. 8
} 
didaftarkan di Lembaga Manajemen Kolektif (LMK) untuk diatur segala hal-hal yang berkaitan dengan royalty.

Setelah hak cipta yang akan menjadi objek jaminan fidusia telah tercatat dan memiliki kepastian hukum, maka sebelumnya terlebih dahulu dilakukan pendaftaran jaminan fidusia di Kantor Jaminan Fidusia. Benda yang dibebani dengan jaminan fidusia wajib didaftarkan, dan dalam hal benda yang dibebani dengan jaminan fidusia berada diluar wilayah negara Republik Indonesia, kewajiban tersebut tetap berlaku. Pendaftaran benda yang dibebani dengan jaminan fidusia dilaksanakan di tempat kedudukan pemberi fidusia, dan pendaftarannya mencakup benda, baik yang berada di dalam maupun di luar wilayah negara Republik Indoneia untuk memenuhi asas publisitas sekaligus merupakan jaminan kepastian terhadap kreditor lainnya mengenai benda yang telah dibebani jaminan fidusia. $^{18}$

18 Budi Agus Riswandi, Permasalahan Pelanggaran dan Langkah Hukum Hak Cipta Atas Musik dan Lagu yang Dituangkan Dalam Bentuk VCD dan DVD,
Untuk Hak Cipta atas lagu, ada beberapa pihak yang bersangkutan yang dimana ada seorang pencipta lagu, produser rekaman, penyanyi, dan pendistribusi cetakan hasil rekaman dari lagu tersebut. Pencipta musik atau lagu mempunyai hak ekonomi yang merupakan hak eksklusif. Dalam sebuah karya cipta lagu, setelah sebuah karya lagu selesai dikerjakan baik itu masih dalam bentuk melodi dengan atau tanpa lirik yang sudah bersifat final, pencipta lagu tersebut secara otomatis memiliki hak atas ciptaan tersebut, baik hak moral maupun hak ekonominya. Hak ekonomi ini dapat berupa hak untuk mengumumkan (performing rights) dan hak menggandakan (mechanical rights). Performing rights atau yang biasa juga disebut dengan performance right adalah satu dari sekumpulan hak yangm diperoleh dari kepemilikan hak cipta, yang memberikan kuasa kepada pemegang hak cipta untuk mengontrol pertunjukan publik sebuah lagu. ${ }^{19}$

Jurnal Hukum, Volume 16, Nomor 4, 573, 2009, hlm. 7

19 Tan Kamello, Hukum Jaminan Fidusia, PT. Alumni, Bandung, 2014, hlm. 120. 
Dalam hal hak cipta akan digandakan, disebarluaskan oleh pihak lain, yakni oleh user atau pemakai, maka user harus meminta izin dari pencipta atau pemegang hak cipta, pada umumnya permintaan izin dari pencipta atau dari pemegang hak cipta dapat diwakili oleh sebuah badan pemungut royalti. Untuk di Indonesia sendiri, baru pencipta atau pemegang hak cipta yang memiliki wadah pemungutan royalti, sebaliknya, untuk karya cipta yang lain belum ada wadah yang mewakilinya seperti seni sastra, seni tari, dan seni drama. ${ }^{20}$

2. Penyerahan Hak Milik atas Objek Jaminan Fidusia jika Objeknya adalah Hak Cipta

\section{a. Penyerahan}

Penyerahan yang juga diistilahkan "levering", "overdracht", "opdracht" adalah merupakan tindakan atau perbuatan pemindahan hak kepemilikan atas sesuatu barang atau benda dari seseorang kepada orang lain. Namun perlu dipahami bahwa peralihan atau berpindahnya hak atas

20 Jurnal Hukum Nomor 23 Volume 10, Konsep Ekonomi dan Hak Moral Pencipta menurut Sistem Civil Law dan Common Law, 2013, hlm.15. kekayaan dari seseorang kepada orang lain dapat terjadi dengan titel umum dan titel khusus. ${ }^{21}$

Sri Soedewi Maschoen Sofwan mengemukakan, mengenai penyerahan di dalam KUHPerdata sering dipakai istilah-istilah lain, tetapi yang mempunyai pengertian yang sama dengan penyerahan, misalnya :

1. Opdracht,

2. Overdracht,

3. Transport ini penyerahan atas benda tak bergerak,

4. Cessie adalah penyerahaan untuk piutang atas nama,

5. Inbreng adalah penyerahan dalam hal warisan.

R. Subekti mengemukakan, perkataan penyerahan mempunyai dua arti. Pertama perbuatan yang berupa penyerahan kekuasaan belaka (feitelijke levering). Kedua perbuatan hukum yang bertujuan memindahkan hak milik kepada orang lain (juridische levering). ${ }^{22}$

Perbedaan antara kedua jenis penyerahan tersebut tampak dengan

\footnotetext{
21 Munir Fuady, Hukum Jaminan Utang, Erlangga, Jakarta, 2013, hlm. 57

${ }^{22}$ Subekti, R. Pokok-Pokok Hukum Perdata. 2010. Intermasa :Jakarta, hlm. 71
} 
nyata pada benda- benda tidak bergerak, dimana hak milik atas benda tidak bergerak diserahkan atau berpindah dengan dilakukannya pencatatan akta dalam register umum dengan apa yang disebut akta transport tetapi terlepas daripada itu terdapat penyerahan nyata. Sebaliknya pada benda-benda bergerak penyerahan nyata dan penyerahan yurudis pada umumnya berpadu berupa penyerahan nyata. Penyerahan (levering) sebagai suatu perbuatan hukum untuk mengalihkan atau memindahkan hak milik oleh seseorang kepada orang lain bukanlah merupakan suatu perbuatan yang berdiri sendiri melainkan perbuatan hukum penyerahan (levering) yaitu tindak lanjut dari suatu perbuatan hukum yang menjadi dasar atau yang disebut sebagai alas hak dari penyerahan itu.

Dalam hal ini perbuatan hukum yang menjadi dasar atau alas hak dari penyerahan itu berupa perjanjian yang bersifat kebendaan antara pihak- pihak yang berdasarkan atas persesuaian kehendak yang bermaksud mengalihkan hak milik atas kebendaan itu.

Sebagaimana telah dikemukakan bahwa dalam KUHPerdata (BW), dikenal dua jenis penyerahan yaitu;

1. Penyerahan secara nyata (feitelijke levering)

2. Penyerahan secara hukum (yuridische levering).

Penyerahan secara nyata (feitelijke levering) yaitu perbuatan berupa penyerahan kekuasaan belaka atau penyerahan secara fisik atas benda yang dialihkan yang biasanya dilakukan dari tangan ke tangan, kecuali barang yang akan diserahkan itu berada dalam suatu gudang, maka penyerahannya cukup dilakukan dengan menyerahkan kunci dari gudang tersebut. Sedangkan, Penyerahan secara hukum (yuridische levering) yaitu perbuatan hukum memindahkan hak milik atas suatu benda dari seorang kepada orang lain, perbuatan hukum mana dilakukan dengan membuat surat atau akta penyerahan dan diikuti pendaftaran di lembaga pendaftaran yang diperuntukkan untuk itu. ${ }^{23}$

\footnotetext{
${ }^{23}$ Munir Fuadi, Jaminan Fidusia, PT. Citra Aditya Bakti, Bandung, 2000, hlm. 86
} 


\section{b. Penyerahan hak milik atas objek jaminan fidusia}

Kemilikan benda yang menjadi objek jaminan fidusia masih merupakan suatu problem hukum yang harus diberikan kejelasannya. Pengertian kemilikan benda dalam hukum jaminan memiliki makna yang luas yakni mencakup hak milik atas benda dan penguasaan atas benda. Jika seorang debitor menyerahkan harta benda sebagai jaminan kepada kreditornya berarti sebagian kekuasaan atas kemilikan benda itu telah beralih kepada kreditor. Berdasarkan Pasal 1 angka 1 Undang-Undang Nomor 42 Tahun 1999 tentang Jaminan Fidusia (UUJF), mengatur bahwa

"Fidusia adalah pengalihan hak kepemilikan suatu benda atas dasar kepercayaan dengan ketentuan bahwa benda yang hak kepemilikannya dialihkan tersebut tetap dalam penguasaan pemilik benda.

Menurut Sri Soedewi Masjcheon Sofwan penyerahan hak milik dalam jaminan fidusia dikenal istilah Constitum Possesorium yang artinya penyerahan hak milik dari debitor kepada kreditor dimana benda yang diserahkan hak miliknya tetap berada dalam penguasaan nyata dari debitor. $^{24}$

Pemberi fidusia menyerahkan secara kepercayaan hak miliknya sebagai jaminan hutang kepada penerima fidusia. Penyerahan hak milik atas benda jaminan fidusia tidaklah sempurna sebagaimana pengalihan hak milik secara kepercayaan itu adalah sifat dinamikanya, overdracht atau levering-nya yaitu penyerahan yuridis sudah terjadi. Kreditor memiliki sebatas jaminan hutang. ${ }^{25}$ Pengalihan hak milik atas benda jaminan fidusia membawa akibat hukum bahwa debitor pemberi jaminan fidusia semula sebagai pemilik kemudian berubah sebagai peminjam pakai. Sebaliknya, dalam hal pihak debitor pemberi jaminan fidusia tetap merupakan pemilik benda jaminan yang memanfaatkan barang tersebut sedangkan kreditor penerima jaminan fidusia hanya menerima penyerahan benda sebagai jaminan hutang dalam arti yuridis.

\footnotetext{
${ }^{24}$ Sri Soedewi Masjcheon Sofwan, Op.Cit., hlm.70

${ }^{25}$ Tan Kamello, Hukum Jaminan Fidusia, PT. Alumni, Bandung, 2014, hlm. 190
} 
Jaminan fidusia merupakan jaminan khusus yang memberikan kepada kreditornya suatu kedudukan yang lebih baik daripada kreditor-kreditor lainnya. Namun demikian pemberian hak kepada kreditor atas benda yang dijaminkan tidak boleh lebih dari kewajiban yang harus ditunaikan oleh debitor kepada pihak kreditor, karena perjanjian jaminan adalah assesoir dari perjanjian pokok yang pada umumnya dalam bentuk utang piutang. Obyek jaminan merupakan pelunasan yang sifatnya substitusi jika debitor tidak melaksanakan prestasinya sebagaimana yang telah diperjanjikan. ${ }^{26}$

Jika dilihat dari bentuk penyerahan, Hak Cipta sebagai Objek Jaminan Fidusia dapat dialihkan hak kepemilikannya secara yuridis berdasarkan Constitutum possesorium, dimana secara yuridis hak milik dimiliki oleh kreditor, tetapi secara nyata benda berada pada penguasan debitor. Jika Hak Cipta akan dialihkan secara

26 D.Y Witanto, Hukum Jaminan Fidusia dalam Perjanjian Pembiayaan Konsumen (Aspek Perikatan, Pendaftaran, dan Eksekusi), Mandar Maju, Bandung, 2015, hlm. 285 keseluruhan, maka pengalihan atas pemegang hak cipta ciptaan tersebut harus di informasikan ke instansi terkait. Berdasarkan hal tersebut, maka perlu dilakukan pendaftaran kembali atas ciptaan tersebut. Pendaftaran Hak Cipta dapat dilakukan melalui beberapa alternatif, yaitu:

1) Secara langsung kepada Direktorat Hak Cipta dan Desain Industri, Direktorat Jenderal Kekayaan Intelektual, Kementrian Hukum dan HAM.

2) Melalui Kantor Wilayah Kementrian Hukum dan HAM Republik Indonesia di seluruh wilayah Indonesia.

3) Melalui Konsultan Hak Kekayaan Intelektual.

Dalam hal hak kepemilikan atas ciptaan tersebut akan dialihkan maka diperlukan beberapa lampiran. Pasal 66 Ayat (2) UUHC mengatur bahwa untuk Pencatatan Ciptaan terlebih dahulu diajukan permohonan secara tertulis oleh Pencipta atau Pemegang Hak Cipta. 


\section{Kesimpulan}

Hak Cipta dalam bentuk ciptaan lagu dapat dibebani jaminan fidusia berdasarkan Undang-Undang Nomor 42 Tahun 1999 tentang Jaminan Fidusia, karena ciptaan lagu merupakan benda bergerak tidak berwujud. Namun ciptaan lagu yang dapat dijadikan objek jaminan adalah ciptaan lagu yang memiliki nilai ekonomis. Nilai ekonomis dari suatu ciptaan itu dapat dilihat dari seberapa banyak royalti yang didapatkan oleh pencipta dari ciptaannya tersebut. Royalti ini dapat dihitung dengan cara menjumlahkan perolehan yang di dapat melalui Performing Right dan Mechanical Right.

Penyerahan Hak milik atas Objek Jaminan Fidusia dalam hal objeknya adalah Hak cipta dapat dilakukan berdasarkan

Constitutum

Possesorium yaitu Penyerahan yang apabila benda yang harus diserahkan karena sesuatu perjanjian lain tetap berada dalam kekuasaan orang yang harus menyerahkannya,

maka hak milik beralih tanpa penyerahan nyata. Hal tersebut dikarenakan pada dasarnya hak cipta khususnya ciptaan lagu merupakan benda bergerak yang tidak berwujud dan hak atas ciptaan lagu yang akan menjadi jaminan masih merupakan hak dari si pencipta, tetapi secara hukum si penerima fidusia memiliki hak atas objek jaminan tersebut.

\section{E. Saran}

Sebaiknya dapat dibentuk suatu lembaga seperti KJPP (Kantor Jasa Penilai Publik) khusus untuk menilai Hak Kekayaan Intelektual yang telah tercatat di Direktorat Jenderal Kekayaan Intelektual agar lembaga fidusia dan juga lembaga-lembaga perkreditan yang lain mendapatkan kejelasan mengenai objek jaminan yang dijaminkan dan dapat menguntungkan kedua belah pihak, dimana para pencipta dapat menjaminkan ciptaannya dan para lembaga penjamin utang juga mendapatkan kejelasan mengenai objek jaminannya. Untuk hak cipta dalam bentuk ciptaan lagu sendiri memang sudah ada LMK yang dapat menghitung royalti dari ciptaan lagu tersebut, tetapi untuk hak cipta yang lainnya belum jelas mengenai penentuan nilainya dan dapat memberatkan pencipta untuk 
menjadikan ciptaannya sebagai agunan.

\section{DAFTAR PUSTAKA}

\section{BUKU}

Afillyana Purba, Gazalba Saleh dan Andriana Krisnawati, , TrIpsWTO dan HUKUM HKI Indonesia, PT Rineka Cipta, Jakarta, 2015.

D.Y Witanto, Hukum Jaminan Fidusia dalam Perjanjian Pembiayaan Konsumen (Aspek Perikatan, Pendaftaran, dan Eksekusi), Mandar Maju, Bandung, 2015.

Henry Soelistyo, Hak Cipta Tanpa Hak Moral, PT. Raja Grafindo Persada, Jakarta, 2011.

Muhammad Abdulkadir, Kajian Hukum Ekonomi Hak Kekayaan Intelektual, PT. Citra Aditya Bakti, Bandung, 2001.

Munir Fuadi, Jaminan Fidusia, PT. Citra Aditya Bakti, Bandung, 2000.

,Hukum Jaminan Utang, Erlangga, Jakarta, 2013.

Subagio Gigih Wijaya, Hak Cipta sebagai Jaminan Utang, Universitas Sebelas Maret, Surakarta, 2010.

Subekti, R. Pokok-Pokok Hukum Perdata. Intermasa :Jakarta, 2010.
Tan Kamello, Hukum Jaminan Fidusia, PT. Alumni, Bandung, 2014.

Hukum Jaminan Fidusia suatu Kebutuhan yang didambakan, Alumni,Bandung, 2006.

\section{JURNAL/SKRIPSI/TESIS/DISER TASI}

Budi Agus Riswandi, Permasalahan Pelanggaran dan Langkah Hukum Hak Cipta Atas Musik dan Lagu yang Dituangkan Dalam Bentuk VCD dan DVD, Jurnal Hukum, Volume 16, Nomor 4, 573, 2009

Hariyani, Iswi dan Cita Yustisia Serfiyani, 2015, Peran HKI dalam Pengembangan Waralaba dan Ekonomi Kreatif, Media HKI, Vol. XII, No.6, November Ditjen HKI, Kemenkumham RI, Jakarta. 2015

Hariyani, Iswi, , Hak Kekayaan Intelektual Sebagai Jaminan Kredit, dalam Media HKI, Vol. VII, No. 03, Juni 2010, Ditjen HKI, Kemenkumham RI, Jakarta. 2010.

Hendra Tanu Atmadja. Konsep Hak ekonomi dan Hak moral Pencipta menurut Sistem Civil Law dan Common Law. Jakarta:Jurnal Hukum Nomor 23 Volume 10, 2015. 
Henry Donald Lbn. Toruan, fidusia

Problematika Implementasi

Pembiayaan Dengan

Perjanjian Jaminan Fidusia, Jurnal Penelitian Hukum DE JURE, ISSN 1410-5632 Vol. 18 No. 2, Juni 2018.

Junaidi Akhmad dan Muhammad Joni. Pemanfaatan Sertifikat HKI Sebagai Collateral Kredit. Jurnal Volume 6, 2011

Maria Alfons, Implementasi Hak Kekayaan Intelektual Dalam Perspektif Negara Hukum, Jurnal legislalasi Indonesia, Vol. 14 No. 03 - September 2017.

Sulasi Rongiyati, Pelindungan Hukum Hak Kekayaan Intelektual Pada Produk Ekonomi Kreatif, Negara Hukum: Vol. 9, No. 1, Juni 2018.

\section{UNDANG-UNDANG}

Undang Nomor 28 Tahun 2014 tentang Hak Cipta

Undang-undang Nomor 42 Tahun 1999 tentang Jaminan Fidusia.

\section{KUHPERDATA}

\section{INTERNET}

http://business-

law.binus.ac.id/2015/10/08/hak-

cipta-sebagai-objekjaminan- 
Soni Ramdani, Hak Cipta Sebagai Objek Jaminan Fidusia dalam Undang-Undang Republik... 